\title{
Estimation of $\mathrm{NH}_{3}$ emissions from a naturally ventilated livestock farm using local-scale atmospheric dispersion modelling
}

\author{
A. Hensen ${ }^{1}$, B. Loubet ${ }^{2}$, J. Mosquera ${ }^{1, *}$, W. C. M. van den Bulk ${ }^{1}$, J. W. Erisman ${ }^{1}$, U. Dämmgen ${ }^{3}$, C. Milford ${ }^{4}$, \\ F. J. Löpmeier ${ }^{3}$, P. Cellier ${ }^{2}$, P. Mikuška ${ }^{5}$, and M. A. Sutton ${ }^{4}$ \\ ${ }^{1}$ Energy research Centre of the Netherlands (ECN), Petten, The Netherlands \\ ${ }^{2}$ Institut National de la Recherche Agronomique (INRA), Thiverval-Grignon, France \\ ${ }^{3}$ Federal Agricultural Research Centre, Braunschweig (FAL), Germany \\ ${ }^{4}$ Centre for Ecology and Hydrology (CEH), Edinburgh, UK \\ ${ }^{5}$ Institute of Analytical Chemistry, ASCR, v.v.i., Brno, Czech Republic \\ *now at: Animal Sciences Group (ASG), Wageningen, Germany
}

Received: 11 September 2008 - Published in Biogeosciences Discuss.: 14 January 2009

Revised: 14 September 2009 - Accepted: 16 September 2009 - Published: 4 December 2009

\begin{abstract}
Agricultural livestock represents the main source of ammonia $\left(\mathrm{NH}_{3}\right)$ in Europe. In recent years, reduction policies have been applied to reduce $\mathrm{NH}_{3}$ emissions. In order to estimate the impacts of these policies, robust estimates of the emissions from the main sources, i.e. livestock farms are needed. In this paper, the $\mathrm{NH}_{3}$ emissions were estimated from a naturally ventilated livestock farm in Braunschweig, Germany during a joint field experiment of the GRAMINAE European project. An inference method was used with a Gaussian-3D plume model and with the Huang 3-D model. $\mathrm{NH}_{3}$ concentrations downwind of the source were used together with micrometeorological data to estimate the source strength over time. Mobile $\mathrm{NH}_{3}$ concentration measurements provided information on the spatial distribution of source strength. The estimated emission strength ranged between $6.4 \pm 0.18 \mathrm{~kg} \mathrm{NH}_{3} \mathrm{~d}^{-1}$ (Huang 3-D model) and $9.2 \pm 0.7 \mathrm{~kg}$ $\mathrm{NH}_{3} \mathrm{~d}^{-1}$ (Gaussian-3D model). These estimates were 94\% and $63 \%$ of what was obtained using emission factors from the German national inventory $\left(9.6 \mathrm{~kg} \mathrm{~d}^{-1} \mathrm{NH}_{3}\right)$. The effect of deposition was evaluated with the FIDES-2D model. This increased the emission estimate to $11.7 \mathrm{~kg} \mathrm{NH}_{3} \mathrm{~d}^{-1}$, showing that deposition can explain the observed difference. The daily pattern of the source was correlated with net radiation and with the temperature inside the animal houses. The daily pattern resulted from a combination of a temperature effect on the source concentration together with an effect of variations in free and forced convection of the building venti-
\end{abstract}

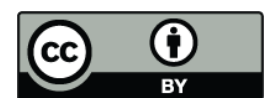

Correspondence to: A. Hensen (hensen@ecn.nl) lation rate. Further development of the plume technique is especially relevant for naturally ventilated farms, since the variable ventilation rate makes other emission measurements difficult.

\section{Introduction}

Atmospheric ammonia $\left(\mathrm{NH}_{3}\right)$ is recognized as a major pollutant impacting on sensitive ecosystems (Bobbink et al., 1992). $\mathrm{NH}_{3}$ deposition may indeed cause soil acidification through nitrification processes (van Breemen et al., 1982), although this depends upon the biological and chemical status of the soil on which it is deposited, and upon the form of $\mathrm{NH}_{\mathrm{x}}$ deposited $\left(\mathrm{NH}_{3}\right.$ or $\left.\mathrm{NH}_{4}^{+}\right)$(Galloway, 1995). Furthermore, atmospheric inputs of $\mathrm{NH}_{\mathrm{x}}$ may induce eutrophication of sensitive ecosystems, as well as decrease their biodiversity (Heij and Schneider, 1991; Bobbink et al., 1992). Agriculture is the main source of $\mathrm{NH}_{3}$ in Europe (Asman, 1992; Heij and Schneider, 1995), and represents more than $80 \%$ of the total anthropogenic input at the global scale (Bouwman et al., 1997). The inventory studies of Pain (1990), of Pain et al. (1998) and Döhler et al. (2002) show that cattle represents the largest source of agricultural $\mathrm{NH}_{3}$ emissions in Europe. These studies as well as Bussink et al. (1998) also showed that between $40 \%$ and $50 \%$ of the emissions from cattle arise from housing and waste storage, housing itself representing about $7 \%$ to $10 \%$. There are also important emissions from pig and poultry production, although the emission factor per animal is smaller for these animals.

Published by Copernicus Publications on behalf of the European Geosciences Union. 


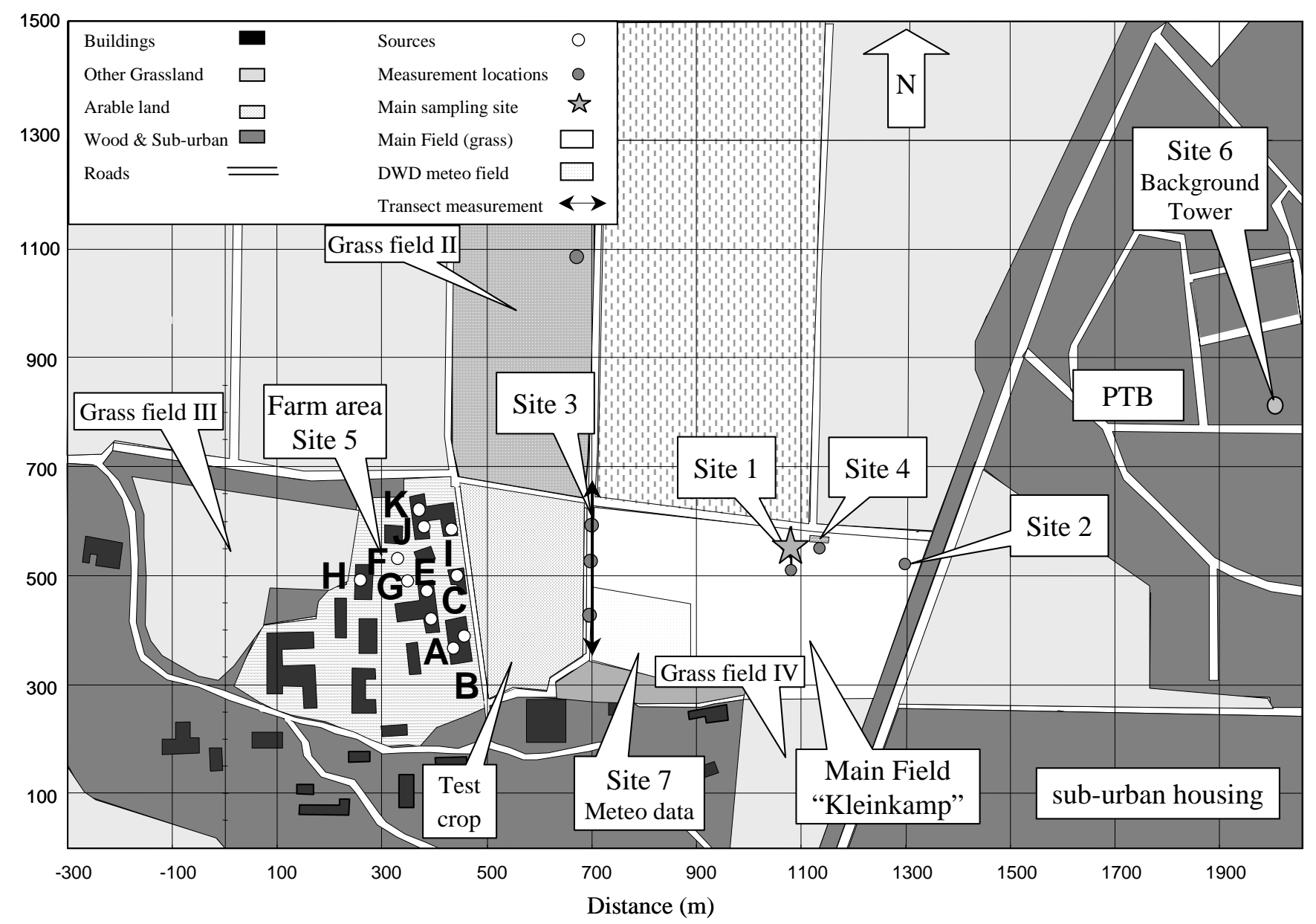

Fig. 1. Overview of the measurement site. The three locations of $\mathrm{NH}_{3}$ air concentration measurement (grey circles) used in this analysis are indicated as Site 1, Site 2 and Site 3. The plume transect measurements were made along the track at Site 3. The sources buildings are labelled from A to K (see Table 1). Distances are shown on the axes of the map in meters (For further description of the site, see Sutton, 2009a).

Measurement of $\mathrm{NH}_{3}$ emissions from naturally ventilated animal houses is technically complex, expensive, and labour intensive (Phillips et al., 2001; Scholtens et al., 2004; Welch et al., 2005a, b). This is primarily due to difficulties in determining the ventilation rate, which varies according to temperature, wind speed, building design, orientation to the wind and animal occupancy (Zhang et al., 2005; Welch et al., 2005b), but also to difficulties inherent in accurately measuring the ammonia concentration on short-time basis (Phillips et al., 2005). However, methods such as the internal or external tracer-ratio techniques or the flux-sampling technique have been successfully tested under real conditions (Demmers et al., 2001; Dore et al., 2004).

Dispersion models can be used as tools to estimate ammonia emissions from animal houses. Among them, the Gaussian-3D model, assuming constant wind-speed $(U)$ and diffusivity $(K z)$ with $z$ is widely used because of its simplicity (Gash, 1985). Analytical models that include variation of
$U$ and $K z$ with height also exist (e.g., Smith, 1957; Philip, 1959; Yeh and Huang, 1975; Huang, 1979; Wilson et al., 1982). The technique using Gaussian models to infer $\mathrm{NH}_{3}$ source from a farm building has been reported in Mosquera et al. (2004). Lagrangian stochastic models have also been tested to infer sources of tracers from concentration measurements downwind of sources such as animal houses (Flesch et al., 2005) cattle feedlots (Flesch et al., 2007) and fields (Loubet et al., 2006; Sommer et al., 2005). More complex Eulerian models have also been used and validated against extensive measurements for estimating emissions of $\mathrm{NH}_{3}$ from buildings (Welch et al., 2005b).

In this paper, a Gaussian 3-D and the Huang (1979) 3-D model are used to estimate the source strength of a set of farm buildings at an experimental field site in Braunschweig (Germany). The stationary measurements of ammonia concentrations were used to infer the source strength of several farm buildings upwind. The inferred emissions are compared 
with inventory emission factors. The daily variability of the emissions is analyzed in comparison with environmental factors such as indoor temperature, external radiation and wind speed. The inferred emission strengths are used in a companion paper (Loubet et al., 2006) as inputs for quantifying the local advection errors induced by the plume coming from the farm on $\mathrm{NH}_{3}$ fluxes measured over a grassland site nearby. This study was performed within the framework of the European project GRAMINAE.

\section{Materials and methods}

\subsection{Measurement site}

The field site is a 12 ha experimental grassland situated in the grounds of the Federal Agricultural Research Centre (FAL), Braunschweig, Germany. Directly adjacent to the field are an experimental farm of the FAL and a station of the German Weather Service (Deutscher Wetterdienst). A more detailed description of the site can be found in Sutton et al. (2009a)

The main source of ammonia in the area is the set of farm buildings A-K (Fig. 1). The distance from west to east is named $x$, whereas the distance from south to north is called $y$, and height above ground is $z$. The distance between the downwind edge of the farm building area and the different sites are: $230 \mathrm{~m}$ for Site 3 where plume measurements were done, and $610 \mathrm{~m}$ for Site 1, were micrometeorological measurements were done. The farm buildings themselves occupy an area of approximately $180 \mathrm{~m}(\mathrm{E}-\mathrm{W}) \times 300 \mathrm{~m}(\mathrm{~S}-\mathrm{N})$. Table 1 gives an estimate of the yearly $\mathrm{NH}_{3}$ emission for each building identified in Fig. 1, based on the emission factors of Döhler et al. (2002) which can be compared to measurement-based estimates emissions factors from Demmers et al. (2001) in Great-Britain, which are 3.5 and $8.9 \mathrm{~kg}$ $\mathrm{NH}_{3}$ animal $^{-1}$ year ${ }^{-1}$, for beef and dairy cattle, respectively.

\subsection{Concentration measurements}

The locations of ammonia concentration measurements are shown as grey dots in Fig. 1. Three AMANDA rotating wet denuders (Wyers et al., 1993) were placed along the N-S transect at Site 3, which gave $\mathrm{NH}_{3}$ concentrations on a $15 \mathrm{~min}$ averaging period at $1 \mathrm{~m}$ height. These instruments were also used to calibrate a fast-response mobile $\mathrm{NH}_{3}$ analyser, itself being moved along the North-West line on the adjacent track (marked as Site 3 in Fig. 1), to measure the plume crosssection at $1.5 \mathrm{~m}$ height. The background $\mathrm{NH}_{3}$ concentrations were measured with a batch denuder system, located at $42 \mathrm{~m}$ height on the top of a tower (Site 6 in Fig. 1), which was located at approximately $1600 \mathrm{~m}$ East-North-East of the farm and 800 North-East of the grassland. Mean and standard deviation of the concentration were estimated for Site 3 over the three measurement systems.

For the mobile measurements, a fast response AMANDA sensor was used, with a time resolution of $30 \mathrm{~s}$. This sys- tem, described in Erisman et al. (2001), is essentially similar to an AMANDA, but the liquid flow is higher $\left(10 \mathrm{ml} \mathrm{min}^{-1}\right.$ instead of $\left.1.6 \mathrm{ml} \mathrm{min}^{-1}\right)$. However, it does not give an absolute concentration, and therefore requires regular calibrations against a reference. The fast response sensor was placed on a trolley and moved along a track through the plume crosssection, and calibrated against the three AMANDA sensors on the same transect (Fig. 1). Note that the calibration was done on differing integration time, as the AMANDA integrates over $15 \mathrm{~min}$. Four subsequent transects were used to evaluate the emission strength with these data.

\subsection{Micrometeorological measurements}

Micrometeorological measurements were performed at Sites 1 and 2. The consensus micrometeorological database derived from the range of measurements performed and detailed in Nemitz et al. (2009) was used in this study. The wind-speed $(U)$, wind-direction $(W D)$, friction velocity $\left(u_{*}\right)$, Monin-Obukhov length $(L)$, and sensible heat fluxes $(H)$, were derived from several ultrasonic anemometer measurements. The latent heat flux $(L E)$ was derived from eddy covariance measurements using the ultrasonic anemometers in combination with a close-path $\mathrm{H}_{2} \mathrm{O}$ analyser (Licor 6262) or open-path $\mathrm{H}_{2} \mathrm{O}$ analyser $\left(\mathrm{KH}_{2} \mathrm{O}\right)$. Air temperature $\left(T_{a}\right)$, relative Humidity $(H R)$ and global $\left(R_{g}\right)$ and net radiation $\left(R_{n}\right)$ were also used.

\section{Inference of the source strength from $\mathrm{NH}_{3}$ concentration}

\subsection{General approach}

In this paper, we compare two models: a 3-D Gaussian plume model that assumes a constant wind speed $(U)$ and diffusivity $\left(K_{z}\right)$ everywhere and the Huang (1979) 3-D model (Huang3D) that assumes that both $U$ and $K_{z}$ are power low functions of height, and a plage source. Moreover, the FIDES2D model, which is also based on Huang (1979) but assumes cross-wind homogeneity of the source (see Loubet et al., 2001 , for details) is also used to estimate the potential error made by neglecting deposition or emission of $\mathrm{NH}_{3}$ from nearby fields.

Three inference methods were used to estimate the source strength variability in space and time:

1. The Gaussian-3D model was used in conjunction with mobile $\mathrm{NH}_{3}$ measurements to estimate the source strength, based on a source distribution equivalent to the emission inventory.

2. The Gaussian-3D model was used in conjunction with concentrations measured at the three locations of Site 3 to estimate the spatial distribution of the source using wind-direction changes. 
Table 1. Description of the farm animal houses, along with their potential emission estimated using German national emission factors (Döhler et al., 2002) and inventoried number of animals. The total yearly emission of the source is $3.5 \times 10^{3} \mathrm{~kg}_{\text {year }}^{-1} \mathrm{NH}_{3}$ and the total number of animals is 553 . The corresponding average daily total emission is $9.6 \mathrm{~kg} \mathrm{~d}^{-1} \mathrm{NH}_{3}$.

\begin{tabular}{|c|c|c|c|c|c|}
\hline $\begin{array}{l}\text { Source number on } \\
\text { map in Fig. } 1\end{array}$ & Animals & Nr. of animals & $\begin{array}{l}\text { Emission factor per animal } \\
\mathrm{kg} \mathrm{NH}_{3} \text { animal }^{-1} \text { year }^{-1}\end{array}$ & $\begin{array}{l}\text { Emission per building } \\
\mathrm{kg} \mathrm{NH}_{3} \text { year }^{-1}\end{array}$ & $\begin{array}{c}\text { Percentage contribution } \\
\%\end{array}$ \\
\hline A & Cattle & 60 & 10.35 & 621 & $18 \%$ \\
\hline B & Cattle & 60 & 10.35 & 621 & $18 \%$ \\
\hline $\mathrm{C}$ & Cattle & 11 & 10.35 & 114 & $3 \%$ \\
\hline D & Cattle & 48 & 10.35 & 497 & $14 \%$ \\
\hline E & Bulls & 64 & 3.89 & 249 & $7 \%$ \\
\hline F & Cattle & 80 & 10.35 & 828 & $24 \%$ \\
\hline G & Calves & 60 & 3.89 & 233 & $7 \%$ \\
\hline $\mathrm{H}$ & Calves & 0 & 3.89 & 0 & $0 \%$ \\
\hline I & Pigs & 80 & 1.97 & 158 & $5 \%$ \\
\hline $\mathrm{J}$ & Pigs & 45 & 1.97 & 89 & $3 \%$ \\
\hline K & Pigs & 45 & 1.97 & 89 & $3 \%$ \\
\hline Total & - & - & - & $3.5 \times 10^{3}$ & $100 \%$ \\
\hline
\end{tabular}

3. The Huang-3D and the Gaussian-3D model were used in conjunction with $15 \mathrm{~min} \mathrm{NH}_{3}$ concentration measured at Site 3 to estimate the time course of the emissions, knowing its spatial variability.

The basic hypothesis made in these approaches are: (a) unless specified, no $\mathrm{NH}_{3}$ deposition is included, as it is considered to be of secondary importance compared with the effect of dispersion on the concentration (e.g., Loubet and Cellier, 2002); (b) no chemical reactions are envisaged, as again the effect on the overall $\mathrm{NH}_{3}$ concentration is not expected to be large on such a small scale (Nemitz et al.; 2009); and (c) the surface characteristics are considered to be homogeneous (i.e., $z_{0}, d$ ), since the models used cannot deal with varying surface roughness, though this is considered to be of minor importance when compared with the potential perturbations induced by the buildings.

With each of the models, the approach is based on the general superposition principle (e.g., Thomson, 1987; Raupach, 1989), which relates the concentration at a location $(x, y, z), \chi(x, y, z)$, to the source strength at another location $\left(x_{s}, y_{s}, z_{s}\right), S_{\text {farm }}\left(x_{s}, y_{s}, z_{s}\right)$, with the use of a dispersion function $D\left(x, y, z / x_{s}, y_{s}, z_{s}\right)\left(\right.$ in $\left.\mathrm{s} \mathrm{m}^{-3}\right)$ :

$\chi(x, y, z)=\chi_{\text {bgd }}+\int_{\text {all } x_{s} \text { and } y_{s}} S_{\text {farm }}\left(x_{s}, y_{s}, z_{s}\right) D\left(x, y, z \mid x_{s}, y_{s}, z_{s}\right) d x_{s}$

where $\chi_{\text {bgd }}$ is the background concentration, assumed to be constant with height. The three models are different in the way they calculate the dispersion function $D\left(x, y, z \mid x_{s}, y_{s}\right.$, $z_{s}$ ) and the different approaches are detailed in the following. In the following the dispersion function will be written $D(x$, $y, z$ ) for simplicity.

\subsection{The Gaussian-3D model}

The Gaussian-3D model is based on the assumptions that $U$ and $K_{z}$ are constant in the whole domain, which implies that $\chi(x, y, z)$ is a function of two independent Gaussian distributions in the horizontal and the vertical planes (see e.g. Lin and Hildemann, 1997). The contribution from a single source located at $\left(x_{s}, y_{s}, z_{s}\right)$ to a point receptor located at $(x$, $y, z)$ is the dispersion function $D\left(x, y, z / x_{s}, y_{s}, z_{s}\right)$, which was calculated using $X=x-x_{s}$ and $Y=y-y_{s}$, as:

$$
\begin{aligned}
& D(X, Y, z)= \frac{Q}{2 \pi \cdot \sigma_{y} \cdot \sigma_{z}} \cdot e^{-Y^{2} /\left(2 \cdot \sigma_{y}\right)^{2}} \\
& \cdot\left(e^{-\left(z-z_{s}\right)^{2} /\left(2 \cdot \sigma_{z}\right)^{2}}+e^{-\left(z+z_{s}\right)^{2} /\left(2 \cdot \sigma_{z}\right)^{2}}\right) \\
& \sigma_{y}=g \cdot X^{h} \cdot z_{o}^{0.2} \cdot T^{0.35} \\
& \sigma_{z}=c \cdot X^{d} \cdot\left(10 \cdot z_{o}\right)^{0.53 \cdot e} \\
& e=X^{-0.22}
\end{aligned}
$$

where $Q$ is the source strength (in $\mathrm{g} \mathrm{s}^{-1} \mathrm{NH}_{3}$ ), $z_{s}$ the height of the source (animal house) (in m), $\sigma_{y}$ and $\sigma_{z}$ are the standard deviation of the lateral and vertical concentration distribution respectively (in $\mathrm{m}$ ), $z_{o}$ is the roughness length (in $\mathrm{m}), T$ is the averaging time, and the parameters $g, h, c$ and $d$ are dependent on the stability classes as detailed in Pasquill (1974). The model used is a multiple plume model based on the superposition of several Gaussian plumes each described by Eqs. (2-3). The concentration at each receptor is the sum of the contribution of all the sources according to Eq. (1). The downwind $(X)$ and crosswind $(Y)$ distances are calculated for each source-receptor couple as follows:

$$
\begin{aligned}
& X=-(x-x s) \cdot \sin (w d)-(y-y s) \cdot \cos (w d) \\
& Y=-(x-x s) \cdot \cos (w d)-(y-y s) \cdot \sin (w d)
\end{aligned}
$$




\subsection{The Huang-3D plage source model}

In this model based on Huang (1979), $D\left(x, z / x_{s}, z_{s}\right)$ is evaluated from a solution of the advection-diffusion equation obtained assuming power law functions for $U(z)$ and $K_{z}(z)$ :

$$
\begin{aligned}
& U(z)=a z^{p} \\
& K z(z)=b z^{n} \\
& D(X, Y, z)=\frac{Q}{\sigma y \sqrt{2 \pi}} \exp \left(-\frac{(Y)^{2}}{2 \sigma y^{2}}\right) \times \frac{(z h)^{(1-n) / 2}}{b \alpha X} \\
& \quad \quad \quad \exp \left(-\frac{a\left(z^{\alpha}+h s^{\alpha}\right)}{b \alpha^{2} X}\right) \times I_{-v}\left(\frac{2 a(z h)^{\alpha / 2}}{b \alpha^{2} X}\right) \\
& \sigma y=\frac{1}{\sqrt{2}} C y x^{\frac{2-m}{2}}
\end{aligned}
$$

Where $\alpha=2+p+n, \nu=(1-n) / \alpha$, and $I_{-\nu}$ ist the modified Bessel function of the first kind of order $-v$, and $C_{y}$ and $m$ were determined from Sutton (1932). The values of $a, b, p$ and $n$ were inferred by linear regression between $\ln (U), \ln \left(K_{z}\right)$ and $\ln (z)$, over the height $2 \times z_{0}-20 \mathrm{~m}$, using $U(z)$ and $K_{z}(z)$ estimated from the Monin-Obukhov similarity theory (see e.g. Kaimal and Finnigan, 1994). Since the model uses stability corrections, its use is limited to values of the Monin Obukhov length $(L)$ and the friction velocity $u_{*}$ such that $|L|>5 \mathrm{~m}$ and $u_{*}>0.2 \mathrm{~m} \mathrm{~s}^{-1}$. In this model, the source is assumed to be a plage source of size $180 \mathrm{~m}$ in $x$ and $300 \mathrm{~m}$ in $y$ located at $230 \mathrm{~m}$ upwind from Site 3 (where concentration is measured).

\subsection{The FIDES-2D model}

The FIDES-2D model was used to evaluate the influence of deposition and emission of $\mathrm{NH}_{3}$ from downwind fields on the estimation of the source strength. FIDES-2D is based on the two-dimensional dispersion model of Huang (1979), which is hence an integration of Eq. (5) over $y$. The dispersion model is coupled with a surface resistance model as detailed in Loubet et al. (2001). The equivalent 2-D source was considered $180 \mathrm{~m}$ long in $x$ and infinite in $y$. The source strength per unit area inferred with FIDES-2D has been multiplied by the equivalent surface of the source: $180 \mathrm{~m} \times 300 \mathrm{~m}$.

\subsection{Spatial distribution of the farm emissions with the Gaussian 3-D model}

The Gaussian-3D model was used to infer the source strength of the farm buildings, using the ammonia concentration measured at the three fixed points at Site $3\left(\mathrm{AM}_{1 . .3}\right)$. The Gaussian-3D model was run in forward mode to estimate the contribution of the eleven sources in Table 1 to the three receptor concentration levels. The sum of the eleven time series is compared with the measured data. The eleven emission levels were modified using the EXCEL (Microsoft) solver function optimizing the correlation coefficient between the measured and modelled concentration time series. The emission strength of the whole farm area $S_{\text {farm }}$ was cal-

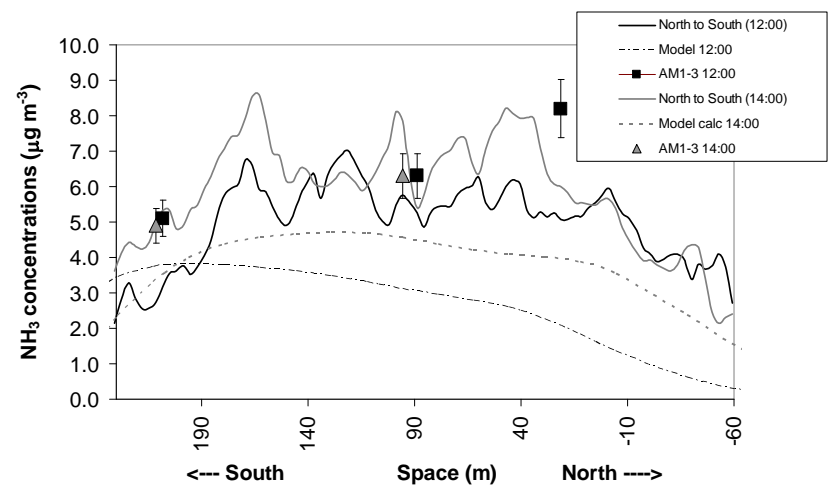

Fig. 2. Two fast-sensor measurements of the $\mathrm{NH}_{3}$ plume crosssection at Site 3 the 12 June 2000 at 12:00 and 14:00. The simultaneous concentrations measurements obtained with the 3 stationary AMANDA systems $\left(\mathrm{AM}_{1 . .3}\right)$ are shown at their corresponding locations in the plume. The figure also shows the plume modelled with the Gaussian-3D model using the source distribution and strength as given in Table 1. The difference between the fast sensor and the stationary AMANDA concentrations is mainly due to the time response of the AMANDA being $15 \mathrm{~min}$ while the fast sensor has a 30 time response. For the $\mathrm{N}-\mathrm{S}$ axis, $0 \mathrm{~m}$ corresponds to the intersection with the main E-W track N of Kleinkamp (Fig. 1).

culated for each $15 \mathrm{~min}$ measurement interval $t$ at the individual receptor locations $\left(\mathrm{AM}_{1 . .3}\right)$ using:

$S_{\text {farm }}\left(t, \mathrm{AM}_{i}\right)=Q_{\text {input }} \times \frac{\chi_{\text {measured }}\left(\mathrm{AM}_{i}\right)-\chi_{\mathrm{bgd}}}{\chi_{\text {model }}\left(\mathrm{AM}_{i}\right)}$

where $Q_{\text {input }}$ is the initial source strength used to estimate $\chi_{\text {model }}, \mathrm{AM}_{i}=\left(\mathrm{AM}_{1}, \mathrm{AM}_{2}\right.$ or $\left.\mathrm{AM}_{3}\right)$ are the receptor locations at Site 3. The time-average and standard deviation of $S_{\text {farm }}$ was then estimated at each receptor locations $\mathrm{AM}_{1 . .3}$. The emission from the farm site were evaluated using all measurements with a wind direction between $200^{\circ}$ and $340^{\circ}$.

\subsection{Time course of the farm emissions}

To evaluate the time course of the farm emissions, the average concentration at Site 3 (over the three sensors) $\chi_{\text {meas }}$ (Site 3) was used. The Huang-3D, FIDES-2D and the Gaussian-3D model were all used in the same manner to evaluate the source strength $S_{\text {farm }}$ simply as:

$S_{\text {farm }}(t)=\frac{\left(\chi_{\text {meas }}(\text { Site } 3)-\chi_{\text {bgd }}\right)}{D\left(X_{\text {Site } 3}, Y_{\text {Site } 3}, z=1 \mathrm{~m}\right)}$

Where $X_{\text {Site } 3}$ and $Y_{\text {Site } 3}$ are the coordinates of Site 3, and $D$ is the dispersion function. In the Huang-3D and in the FIDES2D model the source was a plage-source considered homogeneous, whereas in the Gaussian-3D model the source distribution was set to that in Table 1 . The wind sector considered was $240^{\circ}-300^{\circ}$, which corresponds to a sector of $\pm 30^{\circ}$ around the average wind direction as discussed in Sect. 3.3. 
Table 2. Emission estimates using 4 plume transects measured with the fast response sensor (12 June 2000). Uncertainty of the mean is given as standard error.

\begin{tabular}{lccc}
\hline & $\begin{array}{c}\text { Max dispersion } \\
\mathrm{kg} \mathrm{NH}_{3} \mathrm{~d}^{-1}\end{array}$ & $\begin{array}{c}\text { Min dispersion } \\
\mathrm{kg} \mathrm{NH}_{3} \mathrm{~d}^{-1}\end{array}$ & $\begin{array}{c}\text { Average } \\
\mathrm{kg} \mathrm{NH}_{3} \mathrm{~d}^{-1}\end{array}$ \\
\hline Plume 1 & 8.4 & 6.1 & 7.3 \\
Plume 2 & 11.4 & 9.3 & 10.4 \\
Plume 3 & 11.1 & 9.3 & 10.2 \\
Plume 4 & 10.7 & 10.4 & 10.6 \\
Inventory & & & $9.6 \pm 0.78$ \\
\hline
\end{tabular}

\section{Results}

\subsection{Spatial variability of the farm emissions inferred with the fast response $\mathrm{NH}_{3}$ sensor}

Figure 2 shows two $\mathrm{NH}_{3}$ concentration transects across the plume coming from the farm, obtained with the fast response sensor at Site 3. The transects were obtained at midday from 12:00 to 14:00 on 12 June. The absolute concentration differs slightly between the two periods, which could be explained on the basis of differences in wind-speed.

Four plumes obtained with the mobile measurements system were used to evaluate the emission of the farm site. A set of two model runs was performed using the source distribution in Table 1. The potential for large and small initial mixing close to the farm area was evaluated by setting an initial horizontal dispersion at the farm source of either 50 or $10 \mathrm{~m}$. Initial dispersion in the vertical direction was set to $5 \mathrm{~m}$. The two model runs provide concentration patterns along the transect that were compared with the measured concentration levels. The source estimates for the four plumes and two model runs are shown in Table 2. The emission needed in the model to make the output fit with the measurements is about $10 \%$ higher for the plumes $2-4$ compared with the inventory source strength. Including plume 1 , the emission estimate equals the inventory estimate at $9.6 \mathrm{~kg} \mathrm{NH}_{3} \mathrm{~d}^{-1}$.

The mobile plume measurements show the shape of the plume providing information on the lateral dispersion. The model runs for these plumes showed that the lateral dispersion in the model corresponds with the measurement data at a roughness length $z_{o}=0.2 \mathrm{~m}$. The mobile measurements only covered a small time-period and were hard to do during the night. Therefore, the spatial distribution of the sources within the farm area was evaluated further using the three AMANDA stations $\mathrm{AM}_{1}-\mathrm{AM}_{3}$ at Site 3. Using the source distribution of Table 1 (emission inventory), and tuning the overall source strength $S_{\text {fam }}$, the modelled and measured concentration patterns for the three AMANDA locations showed low correlation coefficients of $R=0.36,0.30$ and 0.20 , respectively (Table 3 ). The model calculations were used to obtain insight in the source-receptor relation for each measurement location. Sources A, B, D and F give the highest contribution to the modelled signal at the three receptor locations. The time series of the estimated $S_{\text {farm }}$ (Eq. 5) were used to estimate the average, standard deviation and median (Table 3). The average emission level obtained in this way was $9.8 \pm 0.8 \mathrm{~kg} \mathrm{NH}_{3} \mathrm{~d}^{-1}$, which is close to the expected level of $9.6 \mathrm{~kg} \mathrm{NH}_{3} \mathrm{~d}^{-1}$. The uncertainty range of $0.8 \mathrm{~kg} \mathrm{NH}_{3} \mathrm{~d}^{-1}$ was obtained from the standard errors in Table 3. The standard deviation of the source estimate is about $100 \%$ this is a combination of uncertainty in the method and of the actual temporal variation of the source strength (discussed below).

In a second step, the correlation between the measured and modelled concentration pattern at Site 3 was optimised by modifying the source distribution. The results are shown in Table 4 . The source distribution estimated by this means shows a decreased contribution from sources A, E and F, and an increase in the emission from $\mathrm{B}$ and $\mathrm{C}$. The correlation between measured and modelled concentration patterns increased to $R=0.5$ and 0.49 for stations AM1 and AM2. No significant effect is observed for AM3. The revised total source strength estimate obtained from the time-series at this source distribution is $9.2 \mathrm{~kg} \mathrm{NH}_{3} \mathrm{~d}^{-1}$. Accounting for simple uncertainty in estimates by system AM1-3 ( $n=3)$ gives a standard error of $1.6 \mathrm{~kg} \mathrm{NH}_{3} \mathrm{~d}^{-1}$, which gives a conservative estimate of the uncertainty. Conversely, given the large sample sizes ( $n=286$ to 441 ), standard errors for the individual AMANDA systems are in the range $0.2-0.6 \mathrm{~kg} \mathrm{NH}_{3} \mathrm{~d}^{-1}$.

Figure 3 shows an illustration of the measured and modelled concentrations using the Gaussian-3D model for AM13 at Site 3 over a two-day period using the adjusted source distribution. The correlation coefficient in Table 4 shows that $10-25 \%$ of the temporal variation can be explained. The differences are expected due to the assumption of a constant source-strength with time. This shows that the combination of time variation in meteorological conditions and the spatial variability of the source can explain part of the variability in the concentration, but not all.

Table 5 gives the estimated source strength using the Gaussian-3D model, as well as the source strength estimated using the emission factors of Döhler et al. (2002). The modification in the source distribution, which was done in order to increase the correlation between measurements and model, suggests that the sources in the south have a low emission, whereas the sources in the north are a factor 3-5 higher. For building A, E, G the Gaussian-3D model significantly underestimates the relative source strength, whereas it overestimates for buildings $\mathrm{C}, \mathrm{D}$, I, and $\mathrm{K}$.

\subsection{Temporal variability of the farm emissions esti- mated with the Huang 3D model}

Figure 4 shows an example result of inferred source strength $\left(\mathrm{kg} \mathrm{NH}_{3}\right.$ day $^{-1}$ ) using the Huang-3D model for the windsector $240^{\circ}-300^{\circ}$. Corresponding hourly source strengths range 
Table 3. Source-receptor relation and source estimate obtained with the Gaussian-3D model using the spatial source distribution as obtained using the inventory data.

\begin{tabular}{|c|c|c|c|c|c|c|c|c|c|c|c|c|c|c|c|}
\hline & \multicolumn{10}{|c|}{ Contribution in $\%$} & \multicolumn{5}{|c|}{$Q \mathrm{~kg} \mathrm{NH}_{3} \mathrm{~d}^{-1}$} \\
\hline & A & $\mathrm{B}$ & $\mathrm{C}$ & $\mathrm{D}$ & $\mathrm{E}$ & $\mathrm{F}$ & $\mathrm{G} \& \mathrm{H}$ & I & $\mathrm{J}$ & $\mathrm{K}$ & Mean & St. dev & $\mathrm{N}$ & St. error ${ }^{\mathrm{a}}$ & Corr $(R)$ \\
\hline AM1 & 26 & 30 & 3 & 9 & 4 & 13 & 3 & 6 & 2 & 2 & 7 & 4 & 456 & 0.19 & 0.36 \\
\hline AM2 & 22 & 26 & 4 & 11 & 6 & 15 & 4 & 7 & 3 & 3 & 10 & 10 & 568 & 0.42 & 0.30 \\
\hline AM3 & 18 & 23 & 4 & 10 & 6 & 19 & 5 & 8 & 3 & 4 & 12 & 14 & 459 & 0.65 & 0.20 \\
\hline Mean & or 3 & tion & & & & & & & & & 9.8 & & & & \\
\hline
\end{tabular}

a standard error $=$ st. deviation/sqrt(n)

Table 4. Source-receptor relation and source estimate obtained with the Gaussian-3D model after modification of the spatial distributions of sources with in the farm area.

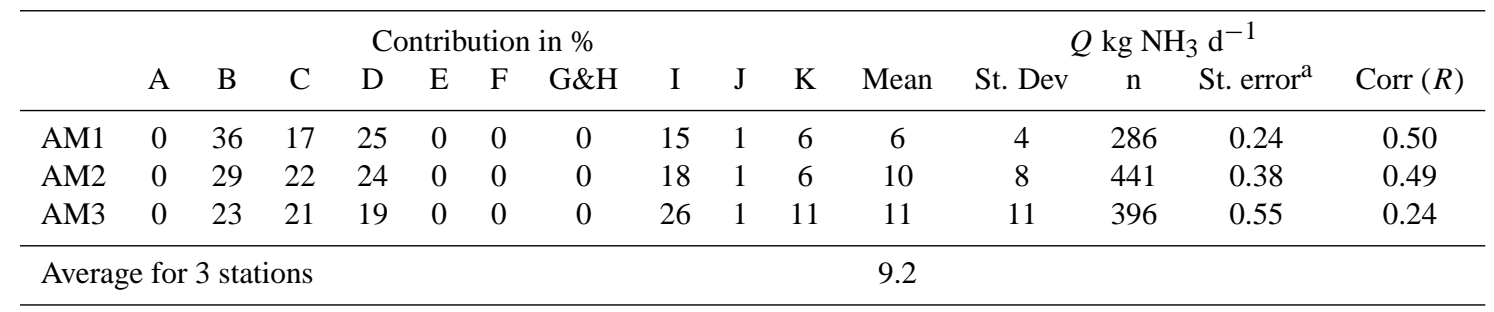

a standard error $=$ st. deviation/sqrt(n)

from 0 to $0.5 \mathrm{~kg} \mathrm{~h}^{-1} \mathrm{NH}_{3}$. Figure 4 shows a clear diurnal variation with a maximum emission at midday and a minimum during the night. This daily variability is not always due to concentration changes, as shown in Fig. 4 (bottom graph) where concentration difference $\chi-\chi_{\text {bgd }}$ is constant and the source strength varies. The variability is also due to the turbulent diffusivity increasing during the day, therefore requiring a larger source to generate a similar concentration at a given distance. Averaging the inferred hourly emission rates over all the available data (for westerly winds), and converting to daily emission rates lead to an average emission of $6.4 \mathrm{~kg} \mathrm{~d}^{-1} \mathrm{NH}_{3}$, with a standard error of $0.18 \mathrm{~kg} \mathrm{~d}^{-1} \mathrm{NH}_{3}$ $(N=495)$.

The inferred emission strength was averaged to hourly values in order to estimate a mean daily pattern (Fig. 5). The daily pattern was observed throughout the period, with a minimum between 01:00 and 02:00 GMT in the morning and a maximum between 07:00 and 09:00 GMT in the morning, then decreasing towards the end of the day. This pattern is partly reflected by the concentration difference between Site 3 and the background concentration, also shown in Fig. 5. Note that there are not many data at night, due to $u_{*}$ or $|L|$ being below the model requirement under stable conditions, so that the results obtained for night-time conditions are based on less data than for the day.

\section{Discussion}

\subsection{Emissions from the farm buildings estimated with different techniques and sensitivity analysis}

The averaged daily emission estimated with the Gaussian$3 \mathrm{D}$ model was found to be $9.2 \pm 0.7 \mathrm{~kg} \mathrm{~d}^{-1} \mathrm{NH}_{3}$, and $6.4 \pm 0.18 \mathrm{~kg} \mathrm{~d}^{-1} \mathrm{NH}_{3}$ ( \pm standard errors) with the Huang-3D model, while it was estimated as $9.6 \mathrm{~kg} \mathrm{~d}^{-1} \mathrm{NH}_{3}$ with the emission factors approach. The inferred emission strength with the Gaussian-3D and the Huang-3D model would represent $3.3 \mathrm{t} \mathrm{NH}_{3}$ year $^{-1}$ and $2.3 \mathrm{t} \mathrm{NH}_{3}$ year $^{-1}$, respectively. Although, the inventory emission factors do not include formal uncertainty estimates, the comparison with the estimates of Demmers et al. (2001) for dairy cattle of $8.9 \mathrm{~kg}$ $\mathrm{NH}_{3}$ animal ${ }^{-1} \mathrm{yr}^{-1}$ compared with $10.35 \mathrm{~kg}_{\text {animal }}{ }^{-1} \mathrm{yr}^{-1}$ of Döhler et al. (2002) suggests that the difference between the Gaussian-3D estimates and the inventory (5\%) is within the range of uncertainties. Conversely, the Huang-3D model was $37 \%$ and $33 \%$ lower than the inventory and Gaussian3D model estimates, respectively. The difference may result from the fact that the Gaussian-3D model uses a constant wind speed and diffusivity profile, and a source height of $4 \mathrm{~m}$ while in the Huang-3D model, the wind speed increases with height and the source is at $1 \mathrm{~m}$ height. It may also be due to the difference in the source treatment: the Gaussian-3D model considers point sources. 

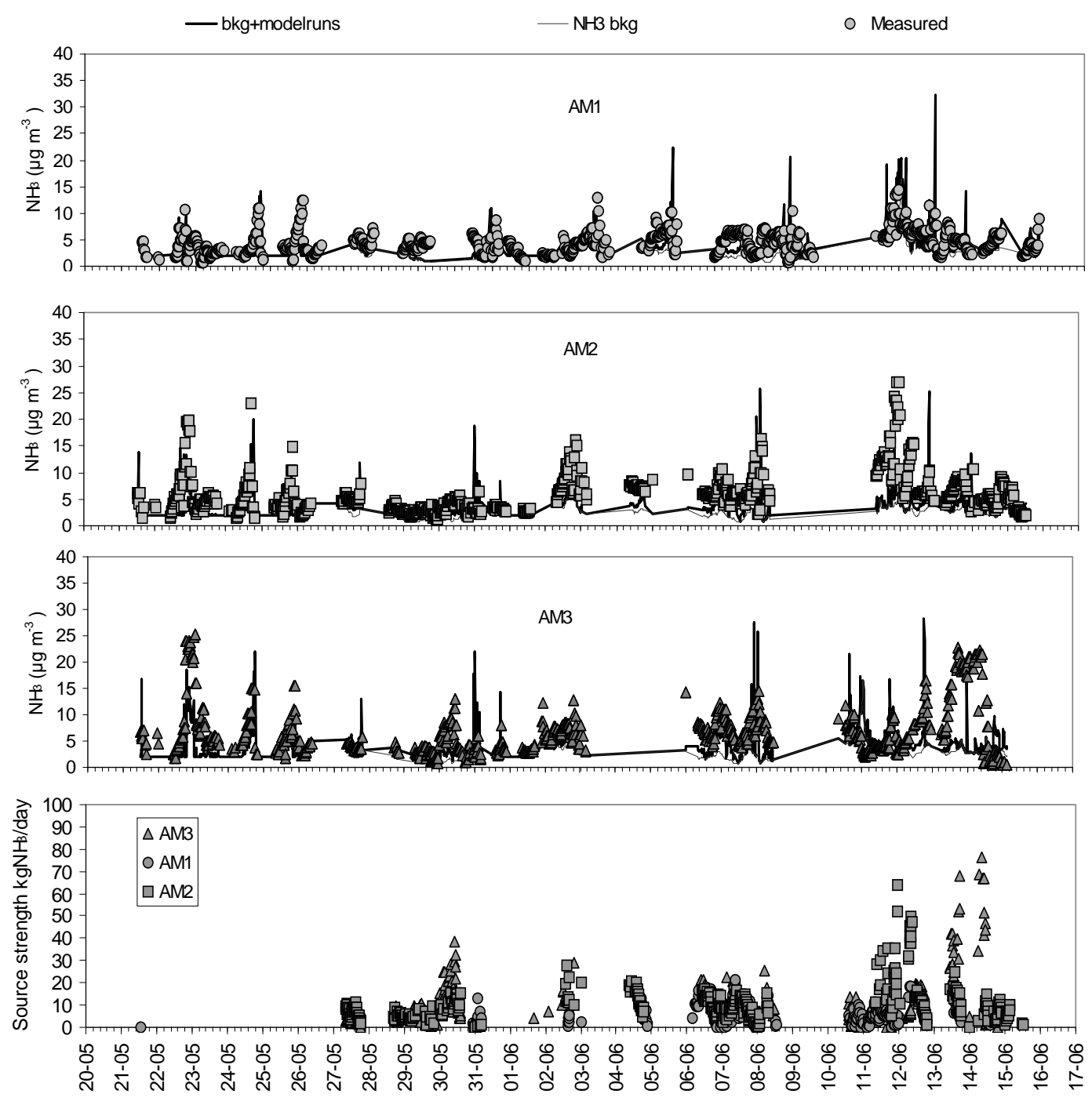

Fig. 3. Example of measured and modelled concentration with the Gaussian-3D model by AM1-3 at Site 3. The source-strengths of the farm buildings were estimated by minimizing the difference between the measured and the modelled concentrations at all locations.

In order to better understand the uncertainty in the different emission estimates a sensitivity analyses was done. The result of this exercise is summarized in Table 6 with the major parameters that might affect the estimation of the emission strength using the two models 3-D dispersion models, as well as the effect of taking into account dry deposition downwind of the source using FIDES-2D.

It can be seen that the Huang-3D and the FIDES-2D models are sensitive to the height of the source and the roughness length with a maximum error around $20 \%$. The Gaussian-3D model calculation showed a similar result for the $z_{o}$ change from $0.1-1$. The Gaussian-3D model uses different $z_{o}$ values per source with larger values for stables at the back of the fram. A change of $50 \%$ of all these values had a $10 \%$ effect on the average emission level.
The difference in source height, already mentioned above, can have a $20 \%$ effect for the Huang-3D model with a lower emission estimates when the source height increases. This will bring the Huang-3D model and the Gaussian-3D model closer together. The source height range in Table 6 only shows a small $(2 \%)$ effect on the Gaussian-3D model estimate. Only when changing the source height further for example from 4 to $10 \mathrm{~m}$ this model would decrease the emission estimate by $8 \%$. For the Gaussian-3D model changing the stability classification at a $15 \mathrm{~min}$ interval from Pasquill class D neutral to $C$ or $E$ would increase or decrease the emission estimate by $40 \%$ respectively. Furthermore, changing the initial dispersion in the wake of the buildings from $5 \mathrm{~m}$ to $10 \mathrm{~m}$ reduced the emission by $20 \%$.

The Huang-3D model is very sensitive to the length (in $\mathrm{x}$ direction) of the source ( $26 \%$ decrease for a $50 \mathrm{~m}$ source and 

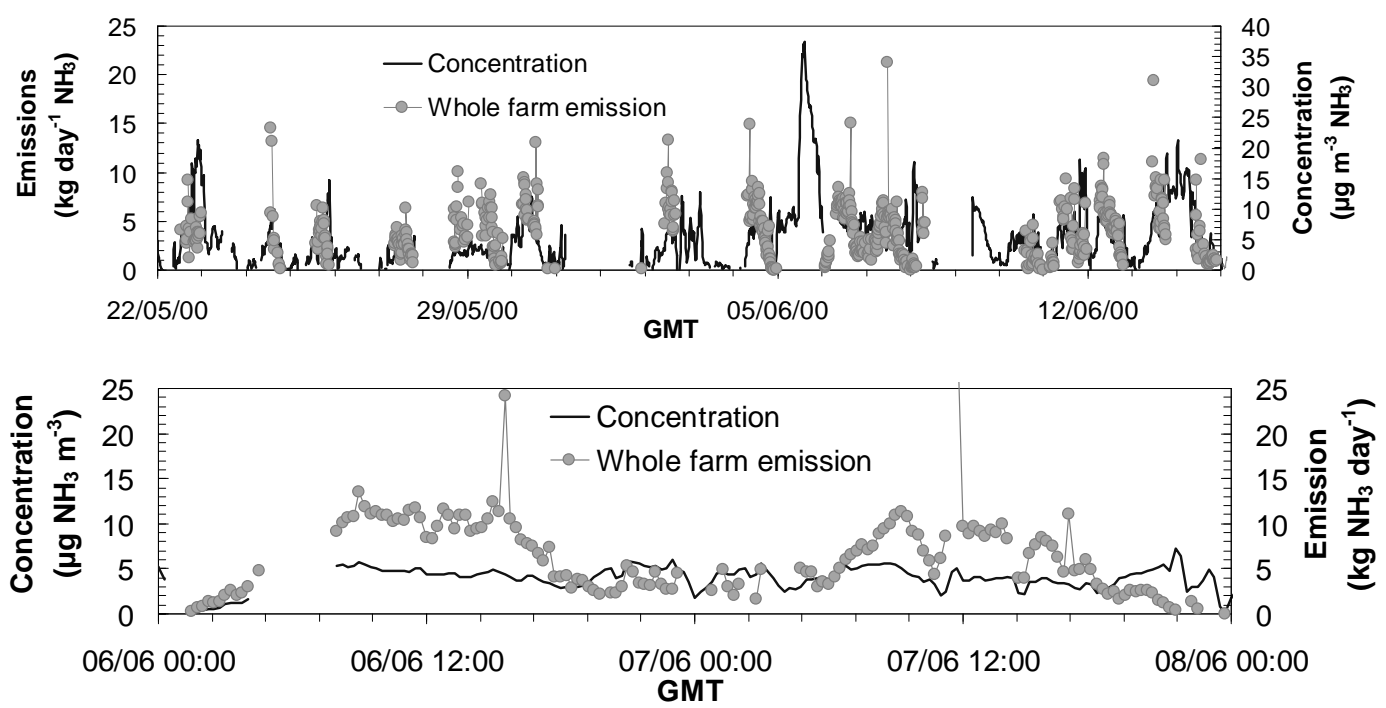

Fig. 4. Top graph: time course of the $\mathrm{NH}_{3}$ emission strength as inferred with the Huang-3D model using the averaged concentration measured for the wind direction $240^{\circ}-300^{\circ}$ at Site 3 and the background concentration measured at Site 6 . Also shown is the concentration difference Site 3-Site 6. Bottom graph: magnification for the period 6-8 June.

Table 5. Ammonia source-strength estimated with the Gaussian-3D model, as compared to that estimated from the emission factors of Döhler et al. (2002). The total amount of ammonia emitted per year estimated using the Gaussian-3D model is $3.3 \times 10^{3} \mathrm{~kg}_{\mathrm{gear}}^{-1} \mathrm{NH}_{3}$ as compared to the inventory estimate of $3.5 \times 10^{3} \mathrm{~kg} \mathrm{year}^{-1} \mathrm{NH}_{3}$. These values correspond to averaged daily emissions of $9.2 \mathrm{~kg} \mathrm{~d}^{-1} \mathrm{NH}_{3}$ and $9.6 \mathrm{~kg} \mathrm{~d}^{-1} \mathrm{NH}_{3}$, respectively.

\begin{tabular}{|c|c|c|c|c|c|c|}
\hline \multirow[b]{2}{*}{$\begin{array}{l}\text { Building } \\
\text { (Fig. 1) }\end{array}$} & \multirow[b]{2}{*}{ Animals } & \multirow[b]{2}{*}{ Number of animals } & \multicolumn{2}{|c|}{ Estimated from emission factors (Döhler et al., 2002) } & \multicolumn{2}{|c|}{$\begin{array}{l}\text { Estimated with the AMANDA measurements } \\
\text { (Site 3) and Gaussian model (this study) }\end{array}$} \\
\hline & & & $\begin{array}{c}\text { Emission per building } \\
\mathrm{kg} \mathrm{NH}_{3} \text { year }^{-1}\end{array}$ & $\begin{array}{l}\text { Percentage contribution } \\
\%\end{array}$ & $\begin{array}{l}\text { Emission per building } \\
\qquad \mathrm{kg} \mathrm{NH}_{3} \text { year }^{-1}\end{array}$ & $\begin{array}{c}\text { Percentage contribution } \\
\%\end{array}$ \\
\hline A & Cattle & 60 & 621 & $18 \%$ & 0 & $0 \%$ \\
\hline $\mathrm{B}$ & Cattle & 60 & 621 & $18 \%$ & 729 & $22 \%$ \\
\hline $\mathrm{C}$ & Cattle & 11 & 114 & $3 \%$ & 559 & $17 \%$ \\
\hline $\mathrm{D}$ & Cattle & 48 & 497 & $14 \%$ & 598 & $18 \%$ \\
\hline $\mathrm{E}$ & Bulls & 64 & 249 & $7 \%$ & 0 & $0 \%$ \\
\hline $\mathrm{F}$ & Cattle & 80 & 828 & $24 \%$ & 4 & $0 \%$ \\
\hline G & Calves & 60 & 233 & $7 \%$ & 0 & $0 \%$ \\
\hline $\mathrm{H}$ & Calves & 0 & 0 & $0 \%$ & 0 & $0 \%$ \\
\hline I & Pigs & 80 & 158 & $5 \%$ & 926 & $28 \%$ \\
\hline $\mathrm{J}$ & Pigs & 45 & 89 & $3 \%$ & 43 & $1 \%$ \\
\hline $\mathrm{K}$ & Pigs & 45 & 89 & $3 \%$ & 483 & $14 \%$ \\
\hline Total & & & $3.5 \times 10^{3}$ & $100 \%$ & $3.3 \times 10^{3}$ & $100 \%$ \\
\hline
\end{tabular}

$151 \%$ increase for a $400 \mathrm{~m}$ source). The measured $\mathrm{NH}_{3}$ concentration at $230 \mathrm{~m}$ downwind from the farm will be lowered by the dry deposition taking place between the farm buildings and Site 3. This was studied with the FIDES-2D model and the effect was in the order of $40 \%$. When correcting both the Gauss model and the Huang 3-D model, the latter will be close to the emission inventory result and the Gauss model estimate will be above that level.
Neglecting the deposition issue for the Gauss model, the different sensitivity runs provide a set of emission estimates that have a standard deviation of $25 \%$ around the emission level of $9.2 \mathrm{~kg} \mathrm{NH}_{3} \mathrm{~d}^{-1}$. This uncertainty range is probably more accurate compared to the calculated standard errors bases on the large number of observations. The freedom of choice in the input parameters for the model would be reduced significantly with data available on the vertical distribution of $\mathrm{NH}_{3}$ downwind of the source. Additional data 
Table 6. Daily emission of the source estimated using the emission factor and the modelling approach, and sensitivity of each estimate to micrometeorological parameters. Standard parameters used were: $z_{s r c}=1.0 \mathrm{~m}, z_{0}=0.10 \mathrm{~m}$, source width $=180 \mathrm{~m}$, and no dry deposition. In the sensitivity analysis, $h_{s r c}$ have been set to 0 and $5 \mathrm{~m}$ height, $z_{0}$ has been set to $0.01 \mathrm{~m}$ and $1.0 \mathrm{~m}$, the source width has been set to 50 and $400 \mathrm{~m}$, and in the deposition sensitivity analysis, the stomatal compensation point $\chi_{s}$ has been set to 0 and $1 \mu \mathrm{g} \mathrm{m}^{-3} \mathrm{NH}_{3}$. The cuticular $R_{w}$ and stomatal resistance $R_{S}$ were estimated as $R_{w}=7 \exp ^{((100-\mathrm{RH}) / 12)}$, and $R_{S}=30 \times\{1+200 / \max (0.01$, St $)\}$, where RH is the relative humidity at $z_{0}^{\prime}$ and $\mathrm{St}$ is the global solar radiation.

\begin{tabular}{|c|c|c|c|c|c|c|}
\hline Methodology & $\begin{array}{l}\text { Daily emission } \\
\text { ( } \pm \text { std. err.) } \\
\text { kg d }^{-1} \mathrm{NH}_{3}(\% \\
\text { change) }\end{array}$ & $\begin{array}{l}\text { Sens. to } \\
h_{s r c} \\
(0-5 \mathrm{~m}) \\
\mathrm{Kg} \mathrm{d}^{-1} \mathrm{NH}_{3} \\
\text { (\% change) }\end{array}$ & $\begin{array}{l}\text { Sens. to } \\
z_{0} \\
(0.01-1.0 \mathrm{~m}) \\
\mathrm{kg} \mathrm{d}^{-1} \mathrm{NH}_{3} \\
(\% \text { change })\end{array}$ & $\begin{array}{l}\text { Source width } \\
(50-400 \mathrm{~m}) \\
\mathrm{kg} \mathrm{d}^{-1} \mathrm{NH}_{3} \\
(\% \text { change })\end{array}$ & $\begin{array}{l}\text { Deposition } \chi_{s} \\
\left(0-2 \mu \mathrm{g} \mathrm{m}^{-3} \mathrm{NH}_{3}\right) \\
\mathrm{kg} \mathrm{d}^{-1} \mathrm{NH}_{3} \\
(\% \text { change })\end{array}$ & $\begin{array}{l}\text { Stability class } \\
\mathrm{C}-\mathrm{E} \\
\mathrm{kg} \mathrm{d}^{-1} \mathrm{NH}_{3} \\
\text { (\% change) }\end{array}$ \\
\hline Emission factors & 9.6 & - & - & - & - & \\
\hline Inverse Huang-3D & $6.4 \pm 0.18^{\mathrm{a}}$ & $\begin{array}{l}6.0-7.5 \\
-3 \%+23 \%\end{array}$ & $\begin{array}{l}5.9-7.7 \\
-6 \%+23 \%\end{array}$ & $\begin{array}{l}16.8-4.2 \\
+151 \%-26 \%\end{array}$ & & \\
\hline Inverse FIDES-2D & $5.7 \pm 0.16^{\mathrm{a}}$ & $\begin{array}{l}5.8-7.2 \\
-4 \%+20 \%\end{array}$ & $\begin{array}{l}5.6-7.4 \\
-6 \%+23 \%\end{array}$ & $\begin{array}{l}4.9-7.6 \\
-19 \%+27 \%\end{array}$ & $\begin{array}{l}8.7-8.5 \\
45 \% 41 \%\end{array}$ & \\
\hline
\end{tabular}

a standard error estimated with 632 data.

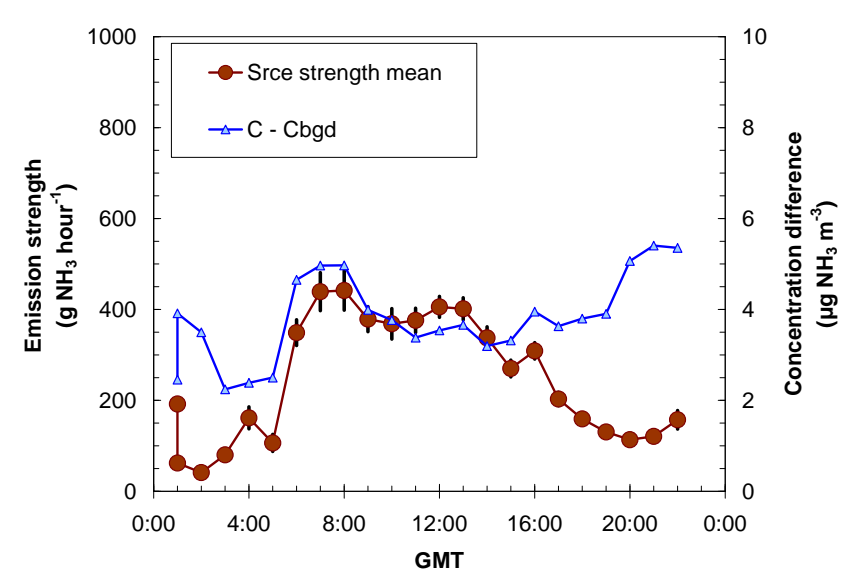

Fig. 5. Diurnal variability of the farm $\mathrm{NH}_{3}$ source strength as estimated with the Huang-3D model for a wind sector of $240^{\circ}-300^{\circ}$. The concentration difference between Site 3 and the background at Site $6\left(\mathrm{C}-\mathrm{C}_{\mathrm{bgd}}\right)$ is also given. The dark circles represent the source strength during the whole period that has been hourly averaged to give the mean source strength for each hour. The error bars are the standard errors.

along a vertical profile up to about $10 \mathrm{~m}$ height would have provided better constraints on the parameters that set the vertical dispersion in the model.

The analysis shows that deposition as well as the source geometry can really influence the emission strength inferred with inverse modeling techniques. However of these two effects, deposition is probably the more problematic in the case of emissions from farm building, since there is a much larger uncertainty on the deposition parameters $\left(R_{S}\right.$ and par- ticularly $R_{w}$ and $\chi_{s}$ ) than on the source geometry. Indeed, the fields in between the source and Site 3 were patches of small crop trials of varying $R_{s}, R_{w}$ and $\chi_{s}$, which makes it difficult to define a unique surface characteristic. Moreover, $R_{w}$ is a very uncertain parameter that has a major influence on local deposition (Flechard et al., 1999; Loubet and Cellier, 2002; Burkhardt et al., 2009). This constitutes a major uncertainty in the dispersion model approach, which is difficult to overcome. One way would be to perform the measurements closer to the source and at higher levels (such as Welch et al., 2005b). However close to the farm, the influence of the farm buildings on the flow would prohibit the use of Gaussian-like models, and would require more sophisticated approaches. This study also suggests that the used of a 3-D model relies on a precise description of the size of the source.

Finally, apart from the model uncertainties there are additional possibilities that can cause a difference between the emission factor calculation and the model result:

1. The small sampling time due to the concentration measurements being done only on the east of the farm, which may hence induce a bias if wind directions show a daily pattern. This was indeed the case, for the west sector at 15:00 there are 4 times more datapoints available compared with 05:00. However, this would have lead to a bias toward higher emission estimates.

2. The experimental farm seemed especially well managed with surfaces regularly cleaned of manure, so that the emission factors estimated from national inventories might indeed be an overestimate for the actual emission level at this site. 


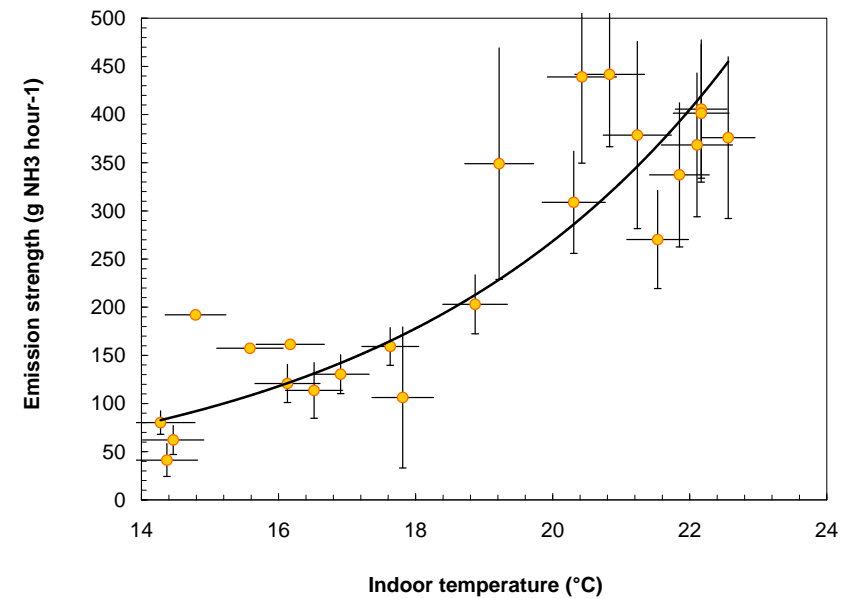

Fig. 6. Hourly averaged emission strength for a wind sector of $240^{\circ}-300^{\circ}$ as a function of hourly mean indoor temperature (measured for the main cattle building $\mathrm{A}$ ). The bold line is a regression with equation: Source $\left[\mathrm{gh}^{-1} \mathrm{NH}_{3}\right]=2.03 \exp \left(0.2342 \times T \quad\left[{ }^{\circ} \mathrm{C}\right]\right)$, $R^{2}=0.771$. The error-bars are \pm standard deviation.

In literature the underestimation of emissions by the dispersion models has been observed before. For example, Welch et al. (2005b) found a collection efficiency of $80 \%$ using the ADMS model in a controlled $\mathrm{NH}_{3}$ release experiment. However, Flesch et al. (2004) found a much better collection efficiency with a methane tracer using a backward Lagrangian Stochastic model under flat terrain conditions. Flesch et al. (2004) also showed that the modelling approach was not reliable under strongly stratified conditions. Michorius et al. (1997) evaluated that the underestimation of $\mathrm{NH}_{3}$ emission by a farm building using a Gaussian-3D approach and concentrations measured at $100 \mathrm{~m}$ varied from $47 \%$ to $68 \%$ of the expected emission.

\subsection{Daily variability of the emissions from a naturally ventilated building}

Figures 4 and 5 show that the emission strength followed a clear diurnal pattern, with a maximum in mid-morning and a minimum at night. Although some of this variability is reflected in the concentration change (Fig. 5), this is not always the case, because of the daily pattern of the turbulent diffusivity. The question arises whether this variability in emission is real or is a bias linked with the inference method. Indeed, the emission from farm houses with forced ventilating systems can be rather constant with time, due to a rather constant indoor temperature regulated by the ventilation system. However, at the FAL farm studied here, most of the buildings are naturally ventilated, which implies that the indoor temperatures fluctuate and that the flow rate through the buildings also changes with environmental conditions (Welch et al., 2005b; Zhang et al., 2005). This seems to be confirmed by Fig. 5 , where one can see a morning maximum, which

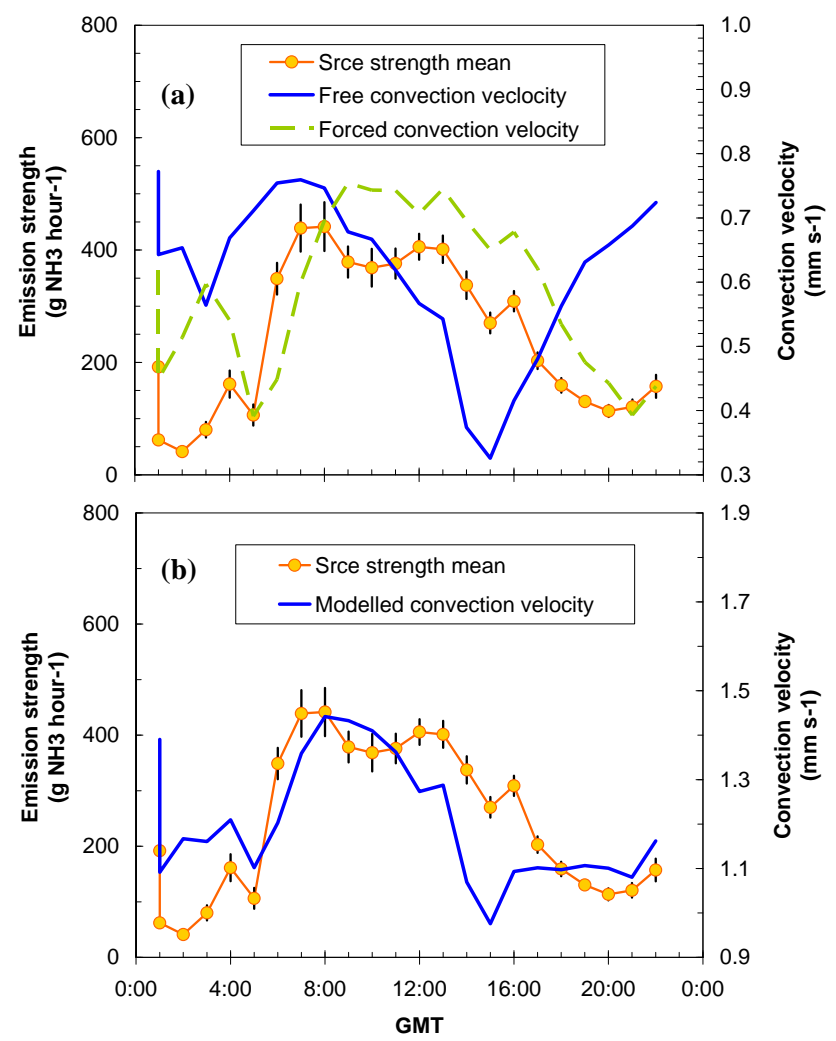

Fig. 7. Hourly averaged emission strength for a wind sector of $240^{\circ}-300^{\circ}$, (a) free and forced convection velocities calculated as $1 / R_{b}$, and (b) resultant total convection velocity (sum of free and forced convection velocities). The error-bars are \pm standard errors. A linear regression between the convection velocity and the emission strength gives an $R^{2}=0.97$.

might for example be due to a flushing out of $\mathrm{NH}_{3}$ accumulated during the night.

Figure 6 shows the hourly-mean emission strength as a function of the indoor temperature of the main cattle building (A in Fig. 1). This suggests that the inferred daily variability of the emission strength is real, since $\mathrm{NH}_{3}$ emission is expected to vary as the exponential function of the temperature according to the Clausius-Clapeyron law (e.g., with a doubling of emission for every $5^{\circ} \mathrm{C}$ increase, Sutton et al., 2001). This dependence of $\mathrm{NH}_{3}$ emissions to indoor temperature was experimentally demonstrated by Zhang et al. (2005) over a range of temperature $5-23^{\circ} \mathrm{C}$. However Zhang et al. found a maximum increase by a factor of 3 over the range of temperature observed here $\left(14-23^{\circ} \mathrm{C}\right)$, whereas Fig. 6 shows an increase of up to a factor of 7 . On the basis of the solubility equilibria, a factor 4 increase would have been expected. This suggests that the response of Fig. 6 may include effects of temperature as well as correlated effects linked with changes in the ventilation rate.

To better understand the factors that cause the observed daily emission pattern, a free and a forced convection 
velocity were calculated by adapting Monteith and Unsworth (1990) and Murphy et al. (1977) approaches, respectively. These velocities were computed as the inverse of the transfer resistance $R_{b}$, using $u_{*}$ as a velocity scale, the difference between indoor and outdoor temperatures, and a characteristic size of the building of $10 \mathrm{~m}$ was taken. Although the expressions from Murphy et al. (1977) are not adapted to free and forced convection in buildings, they can give a good qualitative information on the daily variability of the ventilation rate. They are shown in Fig. 7, calculated from hourly averages, along with the source strength, and the resultant convective velocity (the sum of the two). The daily pattern of free convection (Fig. 7a) shows two maxima, one between $4 \mathrm{~h}$ and $8 \mathrm{~h}$, and the other around $22 \mathrm{~h}$. This pattern is due to a time de-correlation between the indoor and the outdoor temperatures, which might be explained by the building being heated more rapidly than the air in the morning (because of the solar radiation onto the roof and small ventilation), and a longer decrease at night due to the naturally forced ventilation being small at that time. On the opposite, the modelled forced convection velocity follows directly the daily pattern of $u_{*}$.

It can be seen that the resultant convective velocity follows the source strength pattern very well (Fig. 7a). A linear regression between the convective velocity and the emission strength gives an $R^{2}=0.67$. This suggests that the emission pattern observed in Fig. 5 is probably caused by (i) the indoor concentration increasing with indoor temperature, as suggested by Fig. 6 , and (ii) the ventilation rate increasing also during the day as resulting from the combination of natural convection (indoor temperature change), and forced convection (external wind).

\section{Conclusions}

Within the framework of the European GRAMINAE project, an intensive joint field experiment was performed at the FAL research station in Braunschweig (Germany), during May and June 2000. This experiment, summarized in Sutton et al. (2009b) has brought together many atmospheric $\mathrm{NH}_{3}$ concentration measurements techniques located at several sites around a cluster of farm buildings. This gave a great opportunity to use the measured $\mathrm{NH}_{3}$ concentration, as well as mobile fast sensor measurements to infer the emission from the farm building with inverse modelling technique. Three models were used, a Gaussian-3D plume model, the local dispersion model of Huang (1979), and the FIDES-2D model to account for $\mathrm{NH}_{3}$ deposition downwind from the source.

The inferred emission strength was on average $6.4 \mathrm{~kg} \mathrm{~d}^{-1}$ $\mathrm{NH}_{3}$ for the Huang-3D model and $9.2 \pm 0.7 \mathrm{~kg} \mathrm{~d}^{-1} \mathrm{NH}_{3}$ for the Gaussian-3D plume model. The mobile $\mathrm{NH}_{3}$ measurements provided valuable data on the horizontal dispersion of the $\mathrm{NH}_{3}$ plume form the farm houses. These data were used to constrain the dispersion model parameters. Concentration measurements of the vertical distribution of $\mathrm{NH}_{3}$ that could be used to evaluate the vertical dispersion of the $\mathrm{NH}_{3}$ plume were not available but are recommended for similar experiments in future.

A sensitivity analysis showed that the inference method was very sensitive to the deposition scheme used, and when a maximum deposition was applied, the farm emission strength could be increased by $45 \%$. The height and size of the source, the surface roughness, the Pasquill stability classes were found to influence the emission strength estimates both with the Huang-3D and the Gauss model by up to $50 \%$. The source-strength exhibited a clear diurnal cycle with a maximum in the morning (07:00-08:00 GMT) and a minimum at night. This variability can be fully explained by changes in the indoor temperature and the ventilation rate.

In the context of remaining uncertainty in the inventory estimates and lack of independent measurement of $\mathrm{NH}_{3}$ emissions from the buildings, the present work does not fully validate the approach used. However, the application of dispersion models combined with $\mathrm{NH}_{3}$ concentrations measured at large distances downwind, provides an approach in close agreement with the inventory, while this study demonstrates the need to consider other interacting factors, such as dry deposition between the source and the measurement location.

Acknowledgements. The work presented here was partly funded by the EU FP5 GRAMINAE Project (EU contract ENV4-CT980722). Final synthesis of this paper was conducted as part of the NitroEurope Integrated Project We thank the Spanish Commission of Advanced Education and Scientific Research (Dirección General de Enseñanza Superior e Investigación Científica) who provided funding for J. Mosquera to come to the Energy Research Center of the Netherlands (ECN) as a postdoctoral fellow, and the UK Department for Environment Food and Rural Affairs (Defra).

Edited by: J. K. Schjoerring

\section{References}

Asman, W. A. H.: Ammonia emission in Europe: updated emission and emission variations, Report 228471008, National Institute of Public Health and Environmental Protection (RIVM), Bilthoven, The Netherlands, 1992.

Bobbink, R., Boxman, D., Fremstad, E., Heil, G., Houdijk, A., and Roelofs, J.: Critical loads for nitrogen eutrophication of terrestrial and wetland ecosystems based upon changes in vegetation and fauna, in: Critical loads for nitrogen, edited by: Grennfelt, P. and Thörnelöf, E., 41 p., Nordic Council of Ministers, Copenhagen, 1992.

Bouwman, A. F., Lee, D. S., Asman, W. A. H., Dentener, J. F., van de Hoek, K. W., and Olivier, J. J. G.: A global emission inventory for ammonia, Global Biogeochemical Cycles, 11, 561587, 1997.

Burkhardt, J., Flechard, C. R., Gresens, F., Mattsson, M., Jongejan, P. A. C., Erisman, J. W., Weidinger, T., Meszaros, R., Nemitz, E., and Sutton, M. A.: Modelling the dynamic chemical interactions of atmospheric ammonia with leaf surface wetness in a managed 
grassland canopy, Biogeosciences, 6, 67-83, 2009,

http://www.biogeosciences.net/6/67/2009/.

Bussink, D. W. and Oenema, O.: Ammonia volatilization from dairy farming systems in temperate areas: a review, Nutrient Cycling in Agroecosystems, 51, 1352-2310, 1998.

Demmers, T. G. M., Burgess, L. R., Short, J. L., Phillips, V. R., Clark, J. A., and Wathes, C. M.: Ammonia emissions from two mechanically ventilated UK livestock buildings, Atmos. Environ., 33, 107-116, 1999.

Döhler, H., Dämmgen, U., Berg, W., Bergschmidt, A., Brunsch, R., Eurich-Menden, B., Lüttich, M., and Osterburg, B.: Adaptation of the German emission calculation methodology to international guidelines, determination and forecasting of ammonia emissions from German agriculture, and scenarios for reducing them by 2010, Umweltbundesamt (Berlin), Forschungsbericht 299, UBA FB000249, 2002 (in German, summary in English).

Dore, C. J., Jones, B. M. R., Scholtens, R., Huis in’T Veld, J. W. H., Burgess, L. R., and Phillips, V. R.: Measuring ammonia emission rates from livestock buildings and manure stores - Part 2: Comparative demonstrations of three methods on the farm, Atmos. Environ., 38, 3017-3024. 2004.

Erisman, J. W., Otjes, R., Hensen, A., Jongejan, P., v. d. Bulk, P., Khlystov, A., Mols, H., and Slanina, S.: Instrument development and application in studies and monitoring of ambient ammonia, Atmos. Environ., 35, 1913-1922, 2001.

Flesch, T. K., Wilson, J. D., Harper, L. A., and Crenna, B. P.: Estimating gas emissions from a farm with an inverse-dispersion technique, Atmos. Environ., 39, 4863-4874, 2005.

Flechard, C., Fowler, D., Sutton, M. A., and Cape, J. N.: A dynamic chemical model of bi-directional ammonia exchange between semi-natural vegetation and the atmosphere, Q. J. Roy. Meteorol. Soc., 125, 2611-2641, 1999.

Flesch, T. K., Wilson, J. D., Harper, L. A., Todd, R. W., and Cole, N. A.: Determining ammonia emissions from a cattle feedlot with an inverse dispersion technique, Agric. For. Meteorol., 144, 139$155,2007$.

Galloway, J. N.: Acid deposition: perspectives in time and space. Water, Air Soil Pollut., 85, 15-24, 1995.

Gash, J. H. C.: A note on estimating the effect of a limited fetch on micrometeorological evaporation measurements, Bound. Lay. Meteorol., 35, 409-413, 1985.

Heij, G. J. and Schneider, T. (Eds.): Acidification research in the Netherlands, pp. 3-24, Studies in Environmental Science 46, Elsevier, Amsterdam, 1991.

Heij, G. J. and Schneider, T. (Eds.): Dutch Priority Programme on Acidification. Final report No. 300-05, National Institute of Public Health and Environmental Protection (RIVM), Bilthoven, The Netherlands, 1995.

Hensen, A. and Scharff, H.: Methane emission estimates from landfills obtained with dynamic plume measurements, Water, Air Soil Pollut., Kluwer, focus, 1, 455-464, 2001.

Huang, C. H.: A theory of dispersion in turbulent shear flow, Atmos. Environ., 13, 453-463, 1979.

Jarvis, S. C. and Pain, B. F.: Ammonia volatilisation from agricultural land. Proceedings of the Fertiliser Society 298, 35 pp., The Fertiliser Society, Peterborough, 1990.

Lin, J. S. and Hildemann, L. M.: A Generalized mathematical scheme to analytically solve the atmospheric diffusion equation with dry deposition, Atmos. Environ., 31, 59-71, 1997.
Loubet, B. and Cellier, P.: Experimental assessment of atmospheric ammonia dispersion and short-range dry deposition in a maize canopy, Water Air Soil Pollut., 1(5/6), 157-166, 2002.

Loubet, B., Cellier, P., Milford, C., and Sutton, M. A.: A coupled dispersion and exchange model for short-range dry deposition of atmospheric ammonia, Q. J. Roy. Meteorol. Soc., 132, 17331763, 2006.

Loubet, B., Milford, C., Sutton, M. A., and Cellier, P.: Investigation of the interaction between sources and sinks of atmospheric ammonia in an upland landscape using a simplified dispersionexchange model, J. Geophys. Res., 106(D20), 24183-24196, 2001.

Michorius, J. A. T., Hartog, K. D., Scholtens, R., and Harssema, H.: Measuring ammonia emissions from building complexes using the flux frame method and the Gaussian plume model: a feasibility study, Translation - Silsoe Research Institute, 1997.

Milford, C., Theobald, M. R., Nemitz, E., Hargreaves, K. J., Horvath, L., Raso, J., Dämmgen, U., Neftel, A., Jones, S. K., Hensen, A., Loubet, B., Cellier, P., and Sutton, M. A.: Ammonia fluxes in relation to cutting and fertilization of an intensively managed grassland derived from an inter-comparison of gradient measurements, Biogeosciences, 6, 819-834, 2009, http://www.biogeosciences.net/6/819/2009/.

Monteith, J. L. and Unsworth, M. H.: Principles of Environmental Physics, 2nd ed., 291 pp., Arnold, New York, 1990.

Mosquera, J., Monteny, G. J., and Erisman, J. W.: Overview and assessment of techniques to measure ammonia emissions from animal houses: the case of the Netherlands, Environ. Pollut., 135, 381-388, 2005.

Nemitz, E., Hargreaves, K. J., Neftel, A., Loubet, B., Cellier, P., Dorsey, J. R., Flynn, M., Hensen, A., Weidinger, T., Meszaros, R., Horvath, L., Dmmgen, U., Frühauf, C., Löpmeier, F. J., Gallagher, M. W., and Sutton, M. A.: Intercomparison and assessment of turbulent and physiological exchange parameters of grassland, Biogeosciences, 6, 1445-1466, 2009, http://www.biogeosciences.net/6/1445/2009/.

Pasquill, F.: Atmospheric Diffusion, 2nd ed., J. Wiley \& Sons, New York, 1974.

Pain, B. F., van der Weerden, T. J., Chambers, B. J., Phillips, V. R., and Jarvis, S. C.: A new inventory for ammonia emissions from UK agriculture, Atmos. Environ., 32, 309-313, 1998.

Philip, J. R.: The theory of local advection: 1, J. Meteorol., 16, 535-547, 1959.

Phillips, V. R., Lee, D. S., Scholtens, R., Garland, J. A., and Sneath, R. W.: A review of methods for measuring emission rates of ammonia from livestock buildings and slurry or manure stores, part 2: monitoring flux rates, concentrations and airflow rates, J. Agricult. Eng. Res., 78, 1-14, 2001.

Raupach, M. R.: Stand overstorey processes, Philos. Trans. R. Soc. London, Ser. B, 324, 175-190, 1989.

Scholtens, R., Dore, C. J., Jones, B. M. R., Lee, D. S., and Phillips, V. R.: Measuring ammonia emission rates from livestock buildings and manure stores - Part 1: Development and validation of external tracer ratio, internal tracer ratio and passive flux sampling methods, Atmos. Environ., 38, 3003-3015, 2004.

Smith, F. B.: The diffusion of smoke from a continuous elevated point source into a turbulent atmosphere, J. Fluid Mech., 2, 4976, 1957.

Sommer, S. G., McGinn, S. M., and Flesch, T. K.: Simple use 
of the backwards Lagrangian stochastic dispersion technique for measuring ammonia emission from small field-plots, European J. Agronomy, 23, 1-7, 2005.

Sutton, O. G.: A theory of eddy diffusion in the atmosphere, Proc. R. Soc. A, 135, 143-165, 1932.

Sutton, M. A., Nemitz, E., Theobald, M. R., Milford, C., Dorsey, J. R., Gallagher, M. W., Hensen, A., Jongejan, P. A. C., Erisman, J. W., Mattsson, M., Schjoerring, J. K., Cellier, P., Loubet, B., Roche, R., Neftel, A., Hermann, B., Jones, S. K., Lehman, B. E., Horvath, L., Weidinger, T., Rajkai, K., Burkhardt, J., Löpmeier, F. J., and Daemmgen, U.: Dynamics of ammonia exchange with cut grassland: strategy and implementation of the GRAMINAE Integrated Experiment, Biogeosciences, 6, 309-331, 2009a, http://www.biogeosciences.net/6/309/2009/.

Sutton, M. A., Nemitz, E., Milford, C., Campbell, C., Erisman, J. W., Hensen, A., Cellier, P., David, M., Loubet, B., Personne, E., Schjoerring, J. K., Mattsson, M., Dorsey, J. R., Gallagher, M. W., Horvath, L., Weidinger, T., Meszaros, R., Dämmgen, U., Neftel, A., Herrmann, B., Lehman, B. E., Flechard, C., and Burkhardt, J.: Dynamics of ammonia exchange with cut grassland: synthesis of results and conclusions of the GRAMINAE Integrated Experiment, Biogeosciences Discuss., 6, 1121-1184, 2009b, http://www.biogeosciences-discuss.net/6/1121/2009/.

Thomson, D. J.: Criteria for the selection of stochastic models of particle trajectories in turbulent flows, J. Fluid Mech., 180, 529$556,1987$.

Van Breemen, N., Burrough, P. A., Velthorst, E. J., van Dobben, H. F., de Wit, T., Ridder, T. B., and Reijnders, H. F. R.: Soil acidification from ammonium sulphate in forest canopy throughfall, Nature, 288, 548-550, 1982.
Welch, D. C., Colls, J. J., Demmers, T. G. M., and Wathes, C. M. A.: Methodology for the measurement of distributed agricultural sources of ammonia outdoors - Part 1: validation in a controlled environment, Atmos. Environ., 39, 663-672, 2005a.

Welch, D. C., Colls, J. J., Demmers, T. G. M., and Wathes, C. M.: A methodology for the measurement of distributed agricultural sources of ammonia outdoors - Part 2: Field validation and farm measurements, Atmos. Environ., 39, 673-684, 2005 b.

Wilson, J. D., Thurtell, G. W., Kidd, G. E., and Beauchamp, E. G.: Estimation of the rate of gaseous mass transfer from a surface source plot to the atmosphere, Atmos. Environ., 16, 1861-1867, 1982.

Wyers, G. P., Otjes, R. P., and Slanina, J.: A continuous-flow denuder for the measurement of ambient concentrations and surface-exchange fluxes of ammonia, Atmos. Environ., 27A(13), 2085-2090, 1993.

Yeh, G. T. and Huang, C. H.: Three-dimensional air pollutant modeling in the lower atmosphere, Bound. Lay. Meteorol., 9, 381390, 1975.

Zhang, G., Strom, J. S., Li, B., Rom, H. B., Morsing, S., Dahl, P., and Wang, C.: Emission of ammonia and other contaminant gases from naturally ventilated dairy cattle buildings, Biosystems Engineering, 92, 355-364, 2005. 